\title{
Bone morphogenetic protein- 6 enhances gonadotrophin- dependent progesterone and inhibin secretion and expression of mRNA transcripts encoding gonadotrophin receptors and inhibin/activin subunits in chicken granulosa cells
}

\author{
Sara L Al-Musawi, Richard T Gladwell and Philip G Knight \\ School of Biological Sciences, University of Reading, AMS Building, Whiteknights, Reading, RG6 6AJ, UK \\ Correspondence should be addressed to P G Knight; Email: p.g.knight@reading.ac.uk
}

\begin{abstract}
The aims were to examine ovarian expression of bone morphogenetic protein (BMP) ligands/receptor mRNAs in the chicken and to test the hypothesis that theca-derived BMP(s) modulates granulosa cell function in a paracrine manner. RT-PCR revealed expression of multiple BMPs in granulosa and theca cells from prehierarchical and preovulatory follicles with greater expression in theca cells; both cell types expressed BMP receptors-IA, -IB and -II consistent with tissue responsiveness. Preovulatory granulosa cells (F1, F2 and F3/4) were cultured with BMP-6 (expressed by theca but not granulosa) in the presence/absence of $L H$, FSH or 8-Br-cAMP. BMP-6 increased 'basal' and gonadotrophin-induced inhibin-A and progesterone secretion by each cell type but did not enhance the effect of 8-Br-cAMP. This indicates that the observed synergism between BMP-6 and gonadotrophin might involve BMP-induced up-regulation of gonadotrophin receptors. In support of this, BMP-6 alone increased LH-receptor (LHR) mRNA in F1 cells and FSH-receptor (FSHR) mRNA in F1, F2 and F3/4 cells. BMP-6 also enhanced LH/FSH-induced LHR transcript amount in each cell type but did not raise FSHR transcript amounts above those induced by BMP- 6 alone. To further explore BMP6 action on inhibin-A secretion, we quantified inhibin/activin subunits $\left(\alpha, \beta_{A}, \beta_{B}\right)$ mRNAs. Consistent with its effect on inhibin-A secretion, BMP- 6 enhanced 'basal' expression of $\alpha$ - and $\beta_{A}$-subunit mRNA in F1, F2 and F3/4 cells, and $\beta_{B}$-subunit mRNA in F3/4 cells. BMP-6 markedly enhanced FSH/LH-induced expression of $\alpha$-subunit in all follicles and FSH-induced $\beta_{\mathrm{A}}$-subunit in F2 and F3/4 follicles but not in F1 follicles. Neither BMP-6 alone, nor FSH/LH alone, affected 'basal' $\beta_{B}$ mRNA abundance. However, co-treatment with gonadotrophin and BMP-6 greatly increased $\beta_{B}$-subunit expression, the response being lowest in F1 follicles and greatest in $\mathrm{F} 3 / 4$ follicles. Collectively, these results support the hypothesis that intra-ovarian BMPs of thecal origin have a paracrine role in modulating granulosa cell function in the chicken in a preovulatory stage-dependent manner.
\end{abstract}

Reproduction (2007) 134 293-306

\section{Introduction}

The functional left ovary of the laying hen typically contains six to eight large yolk-filled follicles (designated F1-Fn) that have been recruited to a well ordered and rapidly growing preovulatory hierarchy and are destined to ovulate successively at intervals of 24-26 h. Following ovulation of the largest $\mathrm{F} 1$ follicle $(\sim 40 \mathrm{~mm}$ in diameter), the succeeding F2 follicle will advance to the dominant position and so on (Gilbert et al. 1983, Etches \& Schoch 1984). The ordered arrangement of follicles throughout the hierarchy along with the short, well-defined ovulatory cycle permits identification of developmental stages with a considerable degree of precision, conferring a distinct advantage over comparable follicle maturation studies in mammals.
In the hen ovary, the granulosa layer is the principal site of progesterone synthesis (Etches \& Duke 1984); progesterone serves as a precursor for the production of androgens and oestrogens by the neighbouring theca interna and externa cells respectively (Armstrong 1984, Kato et al. 1995). In avian follicles, only the theca layer contains the aromatase enzyme required for oestradiol synthesis (Bahr et al. 1983, Armstrong 1984). The structure of avian follicles is such that granulosa and theca cell layers are easily separated. Moreover, both cell types are amenable to cell culture providing an excellent model system for functional in vitro studies.

In birds as in mammals ovarian folliculogenesis requires the coordinate actions of intra-ovarian and systemic factors. Upon interaction with cognate 
receptors on ovarian granulosa and theca cells, the pituitary gonadotrophins, luteinizing hormone (LH) and follicle-stimulating hormone ( $\mathrm{FSH}$ ) facilitate the production of ovarian steroid and peptide (e.g. inhibin and activin) hormones (Huang \& Nalbandov 1979, Huang et al. 1979, Bahr et al. 1983, Marrone \& Hertelendy 1983, Lee \& Bahr 1989, Lovell et al. 2002a, 2002b). Gonadotrophins activate adenylyl cyclase, generating cAMP and activation of CAMP-dependent protein kinase A (PKA) pathways (Calvo \& Bahr 1982, 1983). Concomitantly, the hydrolysis of phosphoinositides produces other second messengers including inositol triphosphate and 1,2-diacyl-sn-glycerol (DAG) leading to intracellular calcium mobilization and calciumdependent protein kinase $\mathrm{C}$ signal transduction (Marsh 1975, Streb et al. 1983).

Locally produced proteins/peptides implicated in follicle regulation include members of the extensive transforming growth factor (TGF)- $\beta$ superfamily. In vertebrates, the TGF- $\beta$ superfamily comprises over 35 structurally related extracellular growth factors. Members include the inhibins, activins, bone morphogenetic proteins (BMPs), growth differentiation factors, Müllerian inhibiting substance and TGF- $\beta$. Collectively they regulate a multitude of cellular responses including differentiation, proliferation, morphogenesis, chemotaxis and apoptosis. TGF- $\beta$ superfamily members generally exert their biological response by binding to and forming hetero-oligomeric complexes with two types (I and II) of cell-surface receptors, which exhibit integral serine/threonine kinase activity (for review, see de Caestecker 2004). The type-II receptor transphosphorylates a regulatory GS segment (SGSGSG sequence; Wrana et al. 1994) located in the cytoplasmic domain upstream of the serine/threonine kinase domain of the type-I receptor (Huse et al. 1999). This, in turn, phosphorylates and activates downstream intracellular effectors termed receptor-regulated Smad (R-Smads). The activated receptor complex associates with common partner Smads (Co-Smads) and translocates to the nucleus to bind DNA. The recruitment and interaction with various co-activator or co-repressor factors orchestrates the transcription of target gene expression (for review, see Derynck \& Zhang 2003).

Recent studies in mammals have revealed the existence of a functional BMP system in the ovary that appears to have a number of critical roles in the regulation of folliculogenesis and hence female fertility (for reviews, see Knight \& Glister 2003, Shimasaki et al. 2003). Various BMP ligands, receptors, binding proteins and signalling intermediaries are expressed in a cell-specific manner and in vitro studies in several species have demonstrated BMPinduced alterations in steroidogenesis, gonadotrophin responsiveness and cell proliferation in both granulosa and theca cells (rodent: Shimasaki etal. 1999, Otsuka etal. 2001, Erickson \& Shimasaki 2003; porcine: Quinn et al. 2004, Brankin et al. 2005; ovine: Bodensteiner et al. 1999,
McNatty et al. 2003; bovine: Bodensteiner et al. 1999, Glister et al. 2004, 2005). There is also one recent study (Onagbesan et al. 2003) reporting the expression of several BMP ligands and receptors in hen follicles. This study also showed that BMP-4 and-7 enhanced granulosa cell proliferation and gonadotrophin-induced progesterone production.

Given the paucity of information available on BMPs in the avian ovary in the present study, we first used semi-quantitative RT-PCR to compare the pattern of expression of a range of BMP ligands and receptors in chicken granulosa and theca cells recovered from prehierarchical and preovulatory follicles. Having shown that several BMPs (including BMP-6) were expressed by theca but not granulosa cells and that both type-I and type-II BMP receptor (BMPR) transcripts are expressed by granulosa cells, we carried out functional in vitro studies on isolated granulosa cells to test the hypothesis that theca cell-derived BMPs modulate granulosa cell function in a paracrine manner. Secretory responses of the cultured cells to BMP-6, in terms of inhibin-A, inhibin-B and progesterone secretion and cell proliferation/survival were monitored. Real-time quantitative PCR was used to examine the effect of BMP- 6 on basal, gonadotrophinand 8-Br-cAMP-induced expression of mRNA transcripts for gonadotrophin receptors, cytochrome P450 side chain cleavage ( $\left.\mathrm{P}^{4} 50_{\mathrm{scc}}\right)$ and the inhibin/activin subunits $\left(\alpha, \beta_{\mathrm{A}}, \beta_{\mathrm{B}}\right)$.

\section{Materials and Methods}

\section{Experimental animals}

Laying hens (Highline), towards the end of their first year of lay, which were producing at least five eggs in regular sequences, were used. They were individually caged and maintained under a standard long photo schedule of $16 \mathrm{~h}$ light:(lights on at midnight) $8 \mathrm{~h}$ darkness, at an ambient temperature of $21-23{ }^{\circ} \mathrm{C}$. Food and water were provided ad libitum. The time of ovulation for each hen was predicted (Warren \& Scott 1935) and subsequently confirmed from daily recordings of ovipositions, monitored by time-lapse video recording. Hens were killed by cervical dislocation $\sim 10-12 \mathrm{~h}$ after the predicted ovulation of a mid-sequence egg. Ovarian follicles were confirmed to be of a mid-sequence laying cycle by the presence of an additional egg in the oviduct shell gland, thus identified as the consecutive egg to be laid in that clutch. The four largest follicles (F1-F4) of the preovulatory ovarian hierarchy were excised and immediately bathed in sterile Dulbecco's PBS (Sigma UK Ltd). For experiment 1, the prehierarchical follicles of $6-8 \mathrm{~mm}$ in diameter were also collected. 


\section{Isolation of granulosa and theca cells}

Granulosa and theca tissue layers were separated in a laminar flow hood under aseptic conditions (Gilbert et al. 1977). In brief, layers derived from a given follicle position in three to four different hens were combined for each culture experiment. Pooled tissues were enzymatically dispersed as described in Lovell et al. (2002a) except that thecal tissue was dispersed for 45 min rather than 10 min. Cell viability, estimated by trypan blue exclusion (Sigma UK Ltd), was always $>90 \%$ for both cell types. Isolated cells were diluted in incubation medium (medium 199 with $25 \mathrm{mM}$ HEPES, $0.01 \%(\mathrm{v} / \mathrm{v})$ L-glutamine and $1 \%(\mathrm{v} / \mathrm{v})$ antibiotic solution) containing $2 \%(\mathrm{v} / \mathrm{v})$ charcoaltreated foetal bovine serum (Sigma UK Ltd) and plated out in 24-well plates at $0.5 \times 10^{6}$ cells $/ 0.5 \mathrm{ml} /$ well. After culturing for $24 \mathrm{~h}$ at $39^{\circ} \mathrm{C}$, unattached cells were removed by aspiration and the adherent cells were washed thrice with $1 \mathrm{ml}$ serum-free incubation medium. All further incubations were done in serum-free conditions. Incubation buffer $(0.5 \mathrm{ml})$ and test treatments (see below) were added to the appropriate wells. The cells were generally incubated for $3 \times 24 \mathrm{~h}$ treatment periods and conditioned media were replenished with the appropriate test treatments after $24 \mathrm{~h}$. At termination of the culture the media were removed and stored at $-20^{\circ} \mathrm{C}$ and the cell monolayers were washed thrice with PBS prior to RNA purification.

\section{Preparation of treatments}

Ovine (o)LH (NIDDK-oLH-25), oFSH (NIDDK-oFSH19-SIAPP) and recombinant human (rh)BMP-6 (R\&D Systems Europe Ltd, Abingdon, UK) were prepared as stock solutions in PBS containing $0.3 \%(\mathrm{w} / \mathrm{v}) \mathrm{BSA}$ (fraction $\mathrm{V})$. In water, 8-bromoadenosine cAMP (8-BrcAMP; Sigma UK Ltd) was prepared as a $0.2 \mathrm{M}$ stock solution. Solutions were filter sterilized by passing through a $0.2 \mu \mathrm{m}$ membrane filter (Minisart; Sartorius AG, Gottingen, Germany) and diluted to appropriate concentrations in sterile incubation medium. Test substances were diluted in incubation medium and added as $50 \mu \mathrm{l}$ aliquots to duplicate wells (final volume $500 \mu \mathrm{l}$ ) with control wells receiving an equal volume of blank medium.

\section{Experiment 1}

Granulosa and theca cells derived from prehierarchical 6-8 $\mathrm{mm}$ and preovulatory F1 follicles were plated for $24 \mathrm{~h}$ and incubated under serum-free conditions for a further $48 \mathrm{~h}$. Total RNA was extracted for semiquantitative RT-PCR analysis as described below.

\section{Experiment 2}

Granulosa cells derived from preovulatory follicles (F1, $\mathrm{F} 2$ and $\mathrm{F} 3 / 4)$ were cultured with increasing doses of BMP-6 (0, 2, 10 and $50 \mathrm{ng} / \mathrm{ml})$. Cell-conditioned media was collected after $48 \mathrm{~h}$ to be assayed for inhibin-A and progesterone content. At the end of the culture, cells were sonicated in $200 \mu \mathrm{l}$ of ice-cold PBS containing $1 \%$ $(\mathrm{w} / \mathrm{v})$ BSA (protease-free; Sigma UK Ltd), 1\% (v/v) Triton X-100 (Sigma UK Ltd) and $0.1 \%(\mathrm{w} / \mathrm{v})$ sodium azide (Fisher Scientific UK Ltd, Loughborough, UK). The suspensions were stored at $-20^{\circ} \mathrm{C}$ for future analysis of total cellular DNA content.

\section{Experiment 3}

Granulosa cells were cultured with either purified oFSH $(10$ and $100 \mathrm{ng} / \mathrm{ml})$, oLH (10 and $100 \mathrm{ng} / \mathrm{ml}$ ) or 8-Br-cAMP $(0.5 \mathrm{mM})$ individually, or in the presence of rhBMP-6 $(50 \mathrm{ng} / \mathrm{ml}$; dose established from experiment 2 ). The doses of the remaining treatments were previously found to be maximally effective in stimulating inhibin-A and progesterone from preovulatory follicles using the same culture system in our laboratory (Lovell et al. 2002a). Upon termination of the culture at $48 \mathrm{~h}$, cells were analysed for total DNA content and media was harvested for hormone assay. This experiment was replicated six times.

For RNA extraction the experiment was scaled-up with eight replicate wells of 24 -well plates $\left(0.5 \times 10^{6}\right.$ cells $/ 0.5 \mathrm{ml} /$ well) per treatment. Cultures were terminated at $48 \mathrm{~h}$ and cells retrieved for total RNA isolation. After removing conditioned media, cell monolayers were incubated in PBS containing $0.05 \mathrm{M}$ EDTA $(100 \mu \mathrm{l} /$ well) at $38.5^{\circ} \mathrm{C}$ for $10 \mathrm{~min}$. Cells were then collected by gentle scraping and transferred into $1.5 \mathrm{ml}$ non-stick microtubes (Anachem UK Ltd, Luton, Beds, UK) and retrieved by centrifugation (100 $\mathrm{g}$ for $5 \mathrm{~min}$ ). The scaled-up experiment was replicated thrice.

\section{Purification of RNA and synthesis of CDNA}

A standard acid guanidium thiocyanate-phenol-chloroform extraction method (Chomczinski \& Sacchi 1987) was employed for the purification of total RNA. Briefly, cells were lysed in Tri Reagent (Sigma UK Ltd). Upon aqueous phase separation RNA was precipitated in isopropanol (Sigma UK Ltd) and washed in $75 \%$ ( $\mathrm{vol} / \mathrm{vol}$ ) ethanol. The RNA pellet was resuspended in $50 \mu \mathrm{l}$ nuclease-free water treated with RNA Secure (Ambion, Huntington, Cambridgeshire, UK). Potential Genomic DNA contamination was removed with an RNase-free DNase kit (RQ1; Promega UK Ltd). The Tri Reagent extraction process was repeated and the final RNA pellet resuspended in $50 \mu \mathrm{l}$ nuclease-free water; RNA quantity and quality were evaluated by spectrophotometry at 
260/280 nm (GeneQuant RNA/DNA calculator, Amersham Pharmacia Biotech UK Ltd).

First strand cDNA was synthesized from $1 \mu \mathrm{g}$ RNA using the Improm-II Reverse Transcriptase system (using buffers and protocol provided; Promega UK Ltd) in a $20 \mu \mathrm{l}$ reaction. Random hexamer primers $(0.5 \mu \mathrm{g}$; Sigma UK Ltd) and RNA template $(1 \mu \mathrm{g})$ were mixed and denatured $\left(5 \mathrm{~min}\right.$ at $70{ }^{\circ} \mathrm{C}$ ) before rapid chilling in an ice bath for $10 \mathrm{~min}$. $\mathrm{MgCl}_{2}$ (3 mM final), dNTP mix (0.5 mM final), SUPERase In $(20 \mathrm{U} / \mu \mathrm{l}$; Ambion) and Reverse Transcriptase were added $\left(5 \mathrm{~min}\right.$ at $25^{\circ} \mathrm{C}$ ) followed by $40{ }^{\circ} \mathrm{C}$ incubation for $60 \mathrm{~min}$. The reaction was terminated by heat inactivation $\left(15 \mathrm{~min}\right.$ at $\left.70^{\circ} \mathrm{C}\right)$. To specifically degrade RNA in RNA:DNA hybrids, $1 \mu \mathrm{l}$ RNase cocktail $(0.5 \mathrm{U} / \mu \mathrm{l}$ RNase A and $20 \mathrm{U} / \mu \mathrm{l}$ RNase $\mathrm{T} 1$; Ambion) and $0.5 \mu \mathrm{l} \mathrm{RNase} \mathrm{H}(40 \mathrm{U} / \mu \mathrm{l}$; Ambion) was added to each cDNA sample and incubated $\left(37^{\circ} \mathrm{C}\right.$ for $30 \mathrm{~min}$ and $75^{\circ} \mathrm{C}$ for $15 \mathrm{~min}$ ).

\section{Semi-quantitative RT-PCR analysis}

Each reaction consisted of $0.75 \mu$ l diluted (10-fold in TE buffer) cDNA template in a total reaction volume of $12.5 \mu \mathrm{l}$ containing $11.25 \mu \mathrm{l}, 1.1 \times$ Hot Start PCR Master Mix (Abgene, Epsom, Surry, UK) and $0.25 \mu \mathrm{l}$ each forward and reverse primers $(10 \mu \mathrm{mol}$ each; see Table 1). For negative controls, cDNA template was substituted with nuclease-free water. Expression of glyceraldehyde-3-phosphate dehydrogenase (GAPDH) was determined using CDNA template diluted 100-fold. Thermocycling incorporated an initial enzyme activation step at $94{ }^{\circ} \mathrm{C}$ for $15 \mathrm{~min}$ followed by 35 cycles of amplification comprising denaturation at $94{ }^{\circ} \mathrm{C}$ for $20 \mathrm{~s}$, annealing at $68^{\circ} \mathrm{C}$ for $1 \mathrm{~min}$ and extension at $60^{\circ} \mathrm{C}$ for $1 \mathrm{~min}$. Primer sequences were designed to target mRNA sequences based on criteria set by the ABI PRISM primer express software (version 1.5; Perkin-Elmer Applied Biosystems, Warrington, UK). Primer sequences and Entrez accession numbers are outlined in Table 1. Ten microlitres of each PCR product was electrophoresed using a $2 \%$ agarose gel containing $10 \mu \mathrm{g} / \mathrm{ml}$ ethidium bromide.
Samples were run with 20\% (v/v) Blue-Orange Loading dye (Promega), alongside a 100 bp DNA ladder (Promega UK Ltd). Gels were subsequently viewed and photographed under a u.v. transilluminator (u.v. Products Inc., Upland, CA, USA). Representative PCR products for 11 out of the 12 target mRNA sequences (BMP-10 primers did not generate an amplicon) were purified from agarose gels and cloned into pGEM-T Easy Vector (Promega) for sequencing (Cogenics, Takeley, Essex, UK). Sequences of cloned PCR products corresponded to those expected, confirming the specificity of each PCR.

\section{Quantitative real-time RT-PCR analysis}

Reactions were carried out in duplicate and consisted of either $1 \mu \mathrm{l}$ cDNA or $1 \mu \mathrm{l}$ synthetic oligonucleotide standard $(200-0.195 \mathrm{amol} / \mu \mathrm{l})$ in a total volume of $25 \mu \mathrm{l}$ containing $13.5 \mu \mathrm{l}$ Absolute QPCR master mix (Abgene), $2 \mu \mathrm{l}$ each forward and reverse primers (final concentration: $50-900 \mathrm{nM}$ ), $1 \mu \mathrm{l}$ TaqMan probe (final concentration: $100-200 \mathrm{nM}$ ) and $5.5 \mu \mathrm{l}$ nuclease-free water. Controls (no template and no probe) were used throughout. Samples were processed for 40 cycles on an ABI PRISM 7700 Sequence Detection System (PerkinElmer-Applied Biosystems) with the following thermal cycling conditions: $2 \mathrm{~min}$ at $50{ }^{\circ} \mathrm{C}, 15 \mathrm{~min}$ at $95^{\circ} \mathrm{C}, 15 \mathrm{~s}$ at $95^{\circ} \mathrm{C}$ and $1 \mathrm{~min}$ at $60^{\circ} \mathrm{C}$. Probes were $5^{\prime}$-modified with 6-carboxyfluorescein and $3^{\prime}$-modified with carboxytetramethylrhodamine. Primer and probe sequences with corresponding Entrez accession numbers are outlined in Table 2.

\section{Immunoassays}

Concentrations of inhibin-A in granulosa cell-conditioned media were determined by a specific two-site ELISA previously validated for chicken in this laboratory (Lovell et al. 1998, 2000, 2003). The assay employs monoclonal antibodies raised against synthetic peptide fragments of the human inhibin- $\alpha-$ and $-\beta_{A}$-subunits (Muttukrishna et al. 1994). Recombinant human $32 \mathrm{kDa}$ rh inhibin-A (NIBSC, Potters Bar, Herts, UK)

Table 1 Primer sequences used for conventional RT-PCR in this study.

\begin{tabular}{llll}
\hline Target & Accession number & Forward primer 5' to $\mathbf{3}^{\prime}$ & ${\text { Reverse primer 5' to } \mathbf{3}^{\prime}}^{\text {Amplicon size }(\mathrm{bp})}$ \\
\hline BMP-2 & NM_204358 & ttggacaccaggttggtgcatcat & ggcgcttacgctgttgtgtttcg \\
BMP-3 & NM_001034819 & aaacgctccaccaacgtcctgttg & atccactcgctccagccaatgtca \\
BMP-4 & NM_205237 & ctgcccaaagccatgaactcttgC & cacgctgctgaggttgaagacgaa \\
BMP-5 & NM_205148 & gcaagtgaagtgcttttccgctctg & ccagtgtctgaacaatggcgtggt \\
BMP-6 & BM440114 & acgttcccaaaccatgctgtgcac & agctcttgctcatgccacagcgt \\
BMP-7 & AF205877 & aaggattacatccgcgaacgcttcg & ccgtgaagggctgcttgtttgtg \\
BMP-10 & AJ581667 & ggcatccagacagatctatggcacaa & ttccaggttctccaagtccaggagct \\
BMP-15 & AY729025 & atcgctacaacccgcgctactgtaag & tactccttgtagaggatgctgccgtc \\
BMPR-IA & NM_205357 & ttgatggcagcattcgttggatg & caccatatcgtccctttccaacttgc \\
BMPR-IB & NM_205132 & gtttttaccacggaggaggccagct & atcacggtgggcaatagccggttt \\
BMPR-II & NM_001001465 & acggaatcagcgagagccgaatct & ttgtaaggcgtcgtatcggttggg \\
GAPDH & NM_204305 & tgccaacccccaatgtctctgttg & tccttggatgccatgtggaccat
\end{tabular}


Table 2 TaqMan primer and probe sequences used for quantitative PCR in this study.

\begin{tabular}{|c|c|c|c|c|}
\hline Target & Accession number & Forward primer $\left(5^{\prime}\right.$ to $\left.3^{\prime}\right)$ & Reverse $\operatorname{primer}\left(5^{\prime}\right.$ to $\left.3^{\prime}\right)$ & $\begin{array}{c}\text { TaqMan probe } 5^{\prime}[6-F A M] \text { to } 3^{\prime} \\
\text { [TAMRA] }\end{array}$ \\
\hline FSH receptor & NM_205079 & ccgggacattcccacca & tccettcggaatgactctcatc & tgccacagaactgagatttgtcctcacca \\
\hline LH receptor & AB009283 & ttcttcaacggcactggagtc & cattgcattgaggacctgga & ctgcctagctatgggctggaggcc \\
\hline Inhibin $\alpha$ subunit & U48438 & gggctgggacaattggat & actactgccacgggaactgtg & tgcaccccagcagcttcgttttc \\
\hline Inhibin $\beta_{\mathrm{A}}$-subunit & U26946 & caccatccgcctgtttcaac & cctccatatcttctgctccttca & cagcggcagccgaaaggca \\
\hline Inhibin $\beta_{\mathrm{B}}$-subunit & AF055478 & tttagtggtgcaagccg & aagaggcctggagtgcgat & ctcgctgataacaaacacaggatccgg \\
\hline P450scc & D49803 & cacaggctgacaaatgtatcca & gtgctcctcggtgctcttg & acgtttaccgggacatccggctg \\
\hline GAPDH & K01458 & ggagtcaacggatttggcc & ttgccagagaggacggc & tattggccgcctggtcaccagg \\
\hline
\end{tabular}

was used as assay standard and the detection limit was $2 \mathrm{pg} / \mathrm{ml}$.

Inhibin-B concentrations were determined using a specific two-site ELISA previously validated for chicken (Lovell et al. 2000, 2003). The assay employs monoclonal antibodies raised against synthetic peptide fragments of the human $\alpha$ - and $\beta_{\mathrm{B}}$-subunits (Knight \& Muttukrishna 1994, Groome et al. 1996). An in-house standard preparation of pooled porcine follicular fluid was used as the working assay standard. It was previously standardized against rh inhibin-B (Genentech Inc., San Francisco, CA, USA) and parallelism between both dilution curves confirmed by linear regression analysis. The assay detection limit was equivalent to 200 pg rh inhibin-B/ml.

Progesterone concentrations were determined by a competitive ELISA as described by Sauer et al. (1986); the detection limit was $20 \mathrm{pg} / \mathrm{ml}$. Total cellular DNA content was measured by a fluorometric assay as described by Labarca \& Paigen (1980), to determine the effects of treatment on cell proliferation/survival.

In each of the above assays intra- and inter-assay coefficients of variation were below 10 and $12 \%$ respectively.

\section{Statistical analysis}

Data were analysed by two-way ANOVA and provided a significant $F$ ratio $(P<0.05)$ was obtained, post hoc Fisher's protected least significant difference tests were used for pair-wise comparisons of hormone secretion and mRNA expression amongst treatments and amongst cells from follicles of different hierarchical position. Expression of each mRNA was normalized to GAPDH mRNA. There were no significant differences (ANOVA: $P>0.05)$ in GAPDH mRNA expression between cells derived from different follicle classes (F1, F2 and F3/4) under any of the treatments conditions (data not shown). Inhibin-A, inhibin-B and progesterone concentrations in media were normalized to total cellular DNA content at the end of culture. To reduce heterogeneity of variance, data were log-transformed prior to statistical analysis. Unless otherwise stated, numerical values are presented as arithmetic means \pm s.E.M. of three replicate experiments.

\section{Results}

Cells were cultured for a maximum of 3 days (24-h plating followed by 48-h treatment). Results are presented for treatment day 2 during which observed responses to treatments were greatest.

\section{RT-PCR analysis of BMP ligand/receptor expression in granulosa and theca cells from preovulatory $F 1$ and prehierarchical 6-8 $\mathbf{~ m m}$ follicles}

BMP-2, -3, -4 and -5 mRNAs were co-expressed in cultured granulosa and theca cells from preovulatory F1 follicles, albeit at different levels (Fig. 1a). Similarly,

(a)

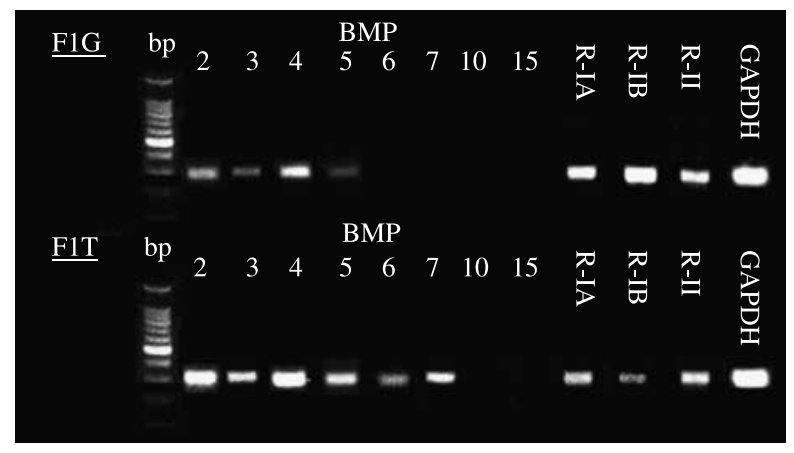

(b)

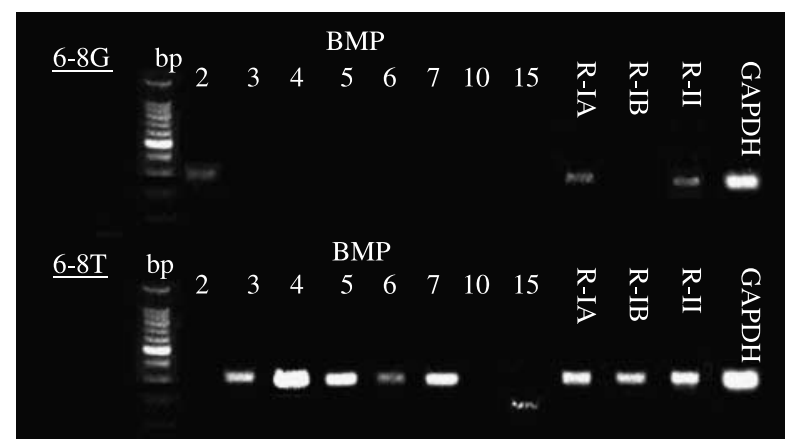

Figure 1 Amplicon bands representing the expression of mRNA transcripts encoding the chicken BMP ligands (BMP-2 to -7, -10 and -15), receptors (BMPR-IA, -IB and -II) and GAPDH in cultured chicken granulosa $(\mathrm{G})$ and theca $(\mathrm{T})$ cells isolated from (a) F1 preovulatory and (b) 6-8 $\mathrm{mm}$ prehierarchical follicles. 
BMPR-IA, -IB and -II were co-expressed in both cell types. Expression of BMP-6, $-7,-10$ and -15 was not detected in F1 granulosa cells but BMP- 6 and -7 were detected in $\mathrm{F} 1$ theca cells. Figure $1 \mathrm{~b}$ shows that only BMP2 and BMPR-IA and-II were detectable in granulosa cells from prehierarchical $6-8 \mathrm{~mm}$ follicles. Correspondingly, theca cells expressed BMP-3, $-4,-5,-6,-7$ and -15 , along with BMPR-IA, -IB and -II, but BMP-2 and -10 expressions were absent. Relative to GAPDH expression, granulosa cells from $\mathrm{F} 1$ follicles appeared to express several BMP ligands (BMP-2,-3 and -4) and all three BMPR forms at much higher amounts than corresponding cells from prehierarchical 6-8 $\mathrm{mm}$ follicles.

\section{Effect of BMP-6 on 'basal' inhibin-A and progesterone secretion by granulosa cells from F1, F2 and F3/4 follicles}

Treatment with BMP-6 elicited significant dose-dependent increases $(P<0.0001)$ in inhibin-A secretion from all three cell populations (Fig. 2a). There was a significant $(P<0.01$ by two-way ANOVA) interaction between the effects of treatment and follicle status: BMP6 induced inhibin-A secretion was greatest from the F3/4 (75-fold), intermediate from the F2 (45-fold) and lowest from the F1 cells (20-fold). BMP-6 treatment increased progesterone secretion ( $\sim$ fourfold; $P<0.0001)$ in all cell cultures (Fig. 2b). However, there was no interaction between the effects of treatment and follicle status $(P>0.05)$.

\section{Effect of BMP-6 alone and in combination with $L H, F S H$ or 8-Br-cAMP, on hormone secretion by granulosa cells from $F 1, F 2$ and $F 3 / 4$ follicles}

Treatment with BMP-6 alone, or either FSH, LH or 8$\mathrm{Br}$-cAMP alone, increased $(P<0.05)$ inhibin-A secretion by F1, F2 and F3/4 granulosa cells (Fig. 3a-C). Co-treatment with BMP-6 further enhanced FSHinduced inhibin-A secretion (above that induced by BMP-6 alone) by F1, F2 and F3/4 granulosa cells but only enhanced $\mathrm{LH}$-induced inhibin-A secretion in $\mathrm{F} 1$
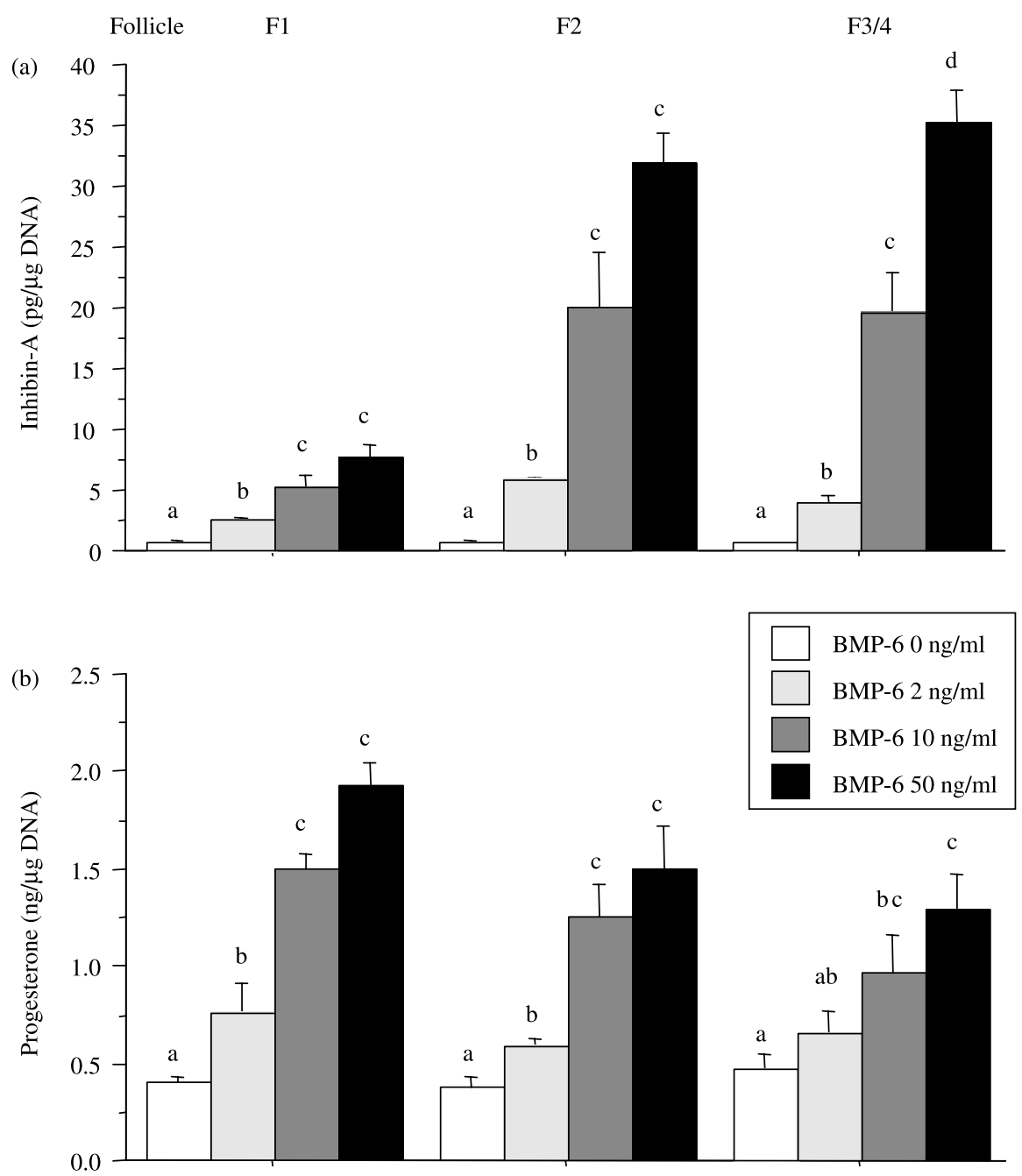

Figure 2 The dose-dependent effect of BMP- 6 $(0,2,10$ and $50 \mathrm{ng} / \mathrm{ml})$ on the secretion of inhibin-A (a) and progesterone (b) by granulosa cells derived from F1, F2 and F3/4 follicles. Values are expressed as means \pm S.E.M. ( $n=6$ independent cultures). Statistical comparisons were made within each follicle class; means without a common letter are significantly different $(P<0.05)$. 

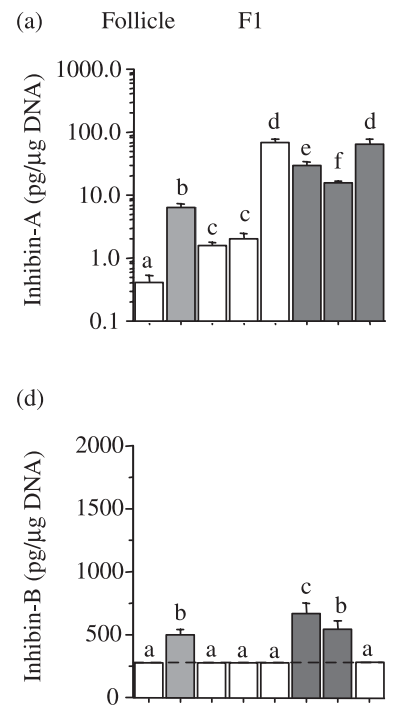

(g)

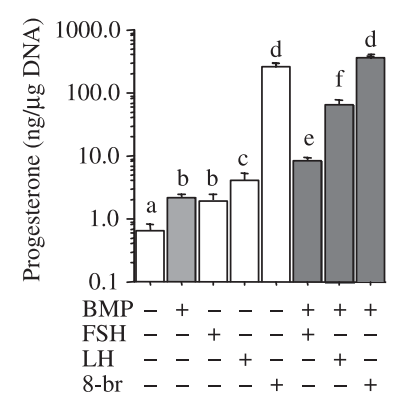

(b) $\mathrm{F} 2$

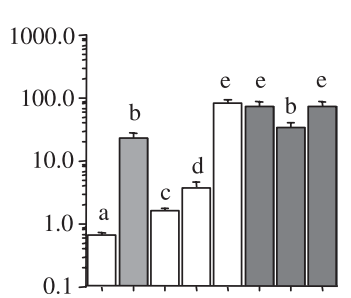

(e)

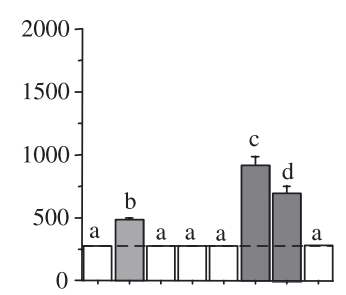

(h)

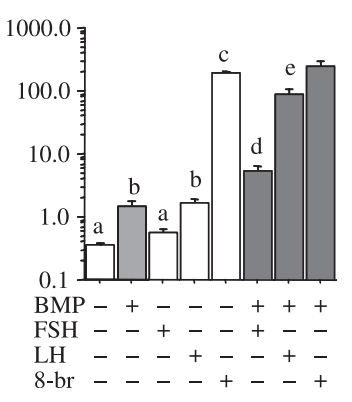

(c)

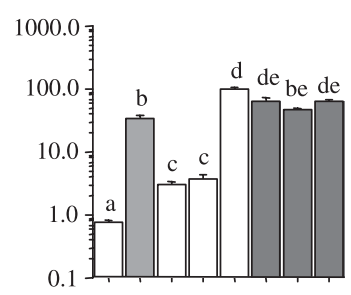

(f)

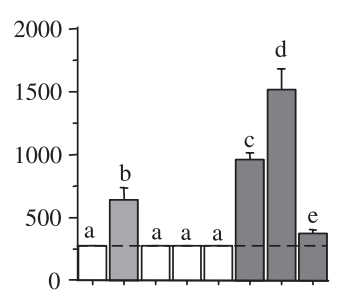

(i)

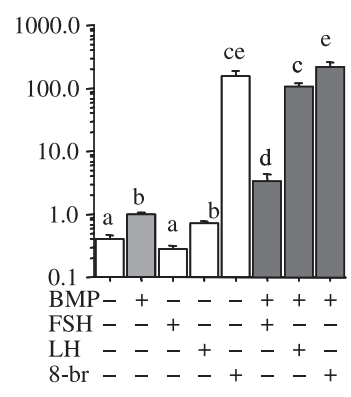

Figure 3 Effect of BMP-6 $(50 \mathrm{ng} / \mathrm{ml})$ with or without FSH/LH (100 ng/ml) or 8-Br-CAMP (0.5 mM) on inhibin-A (a-c; log scale), inhibin- $\mathrm{B}(\mathrm{d}-\mathrm{f})$ and progesterone $(\mathrm{g}-\mathrm{i}$; log scale) secretion by cultured granulosa cells derived from F1, F2 and F3/4 follicles. Values are means \pm S.E.M. $(n=6$ independent cultures); within each panel, means without a common letter are significantly different $(P<0.05)$. The hashed line in $d-f$ indicates the effective detection limit of the inhibin B assay. granulosa cells. BMP-6 did not further enhance 8-Br-cAMP-induced inhibin-A secretion by granulosa cells from any follicle position (Fig. $3 a-c)$.

Inhibin-B secretion by granulosa cells cultured under basal, FSH, LH or 8-Br-cAMP conditions was below the detection limit of the assay (Fig. $3 d-f$ ). Treatment with BMP-6 alone increased inhibin-B secretion by all cells (at least 2.3-fold above detection limit; $P<0.05)$. BMP-6 enhanced $\mathrm{FSH}$-induced inhibin-B secretion by F1 (2.5-fold), F2 (3.5-fold) and F3/4 (3.5-fold) cells $(P<0.05)$. BMP-6 also enhanced LH-induced inhibin-B secretion with maximum stimulation by $\mathrm{F} 3 / 4$ cells $(5.6$-fold; $P<0.05)$. BMP-6 increased 8-Br-cAMP-induced inhibin-B secretion in the F3/4 cells $(1.4$-fold; $P<0.05)$ with no or possibly an inhibitory effect in the F1 and F2 cells.

BMP-6 enhanced $(P<0.05)$ both FSH-induced (up to 12-fold) and LH-induced (up to 100-fold) progesterone secretion by all three cell populations but did not further enhance the marked response to 8-Br-cAMP (Fig. 3g, f and i). The fold enhancement by BMP-6 of FSH-induced progesterone secretion was greatest in F3/4 cells ( $\sim 12$-fold) and lowest in F1 cells $(\sim 4$-fold). The fold enhancement by BMP-6 of
$\mathrm{LH}$-induced progesterone secretion was also greatest in F3/4 cells $(\sim 100$-fold $)$ and lowest in F1 cells ( 18-fold).

\section{Effect of treatments on granulosa cells proliferation/survival}

Treatment with BMP-6 alone promoted a significant increase in total cellular DNA content ( $\sim$ twofold; $P<0.01)$, which was unaffected by follicle hierarchical position (Fig. 4). LH significantly enhanced the response to BMP-6 in F3/4 follicles ( $\sim$ twofold; $P<0.05$ ) but not in $\mathrm{F} 1$ or F2 follicles. There were no significant differences $(P>0.05)$ in DNA content after treatment with either $\mathrm{LH}$, FSH or 8-Br-cAMP alone.

\section{Effects of BMP-6 alone and in combination with FSH, LH or 8-Br-cAMP on steady-state levels of mRNAs encoding the gonadotrophin receptors}

Treatment with BMP-6 alone raised LHR mRNA level in F1 cells $(1.5$-fold; $P<0.01)$ but not in F2 or F3/4 cells (Fig. $5 \mathrm{a}-\mathrm{C}$ ). FSH alone raised LHR transcript level in F2 (1.5-fold; $P<0.01)$ but not in F1 or F3/4 

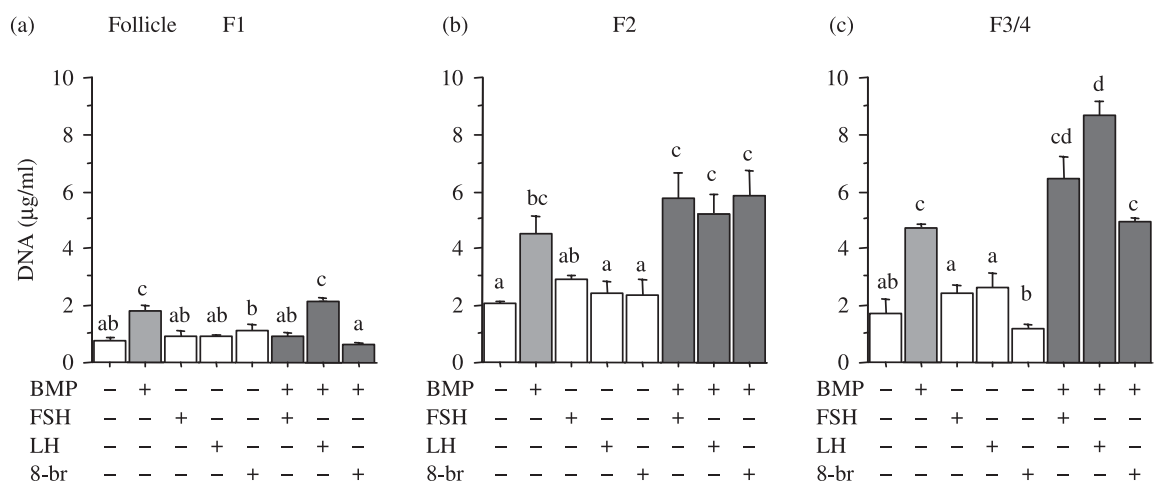

Figure 4 Effect of BMP-6 $(50 \mathrm{ng} / \mathrm{ml})$ with or without $\mathrm{FSH} / \mathrm{LH}(100 \mathrm{ng} / \mathrm{ml})$ or 8 -Br-cAMP $(0.5 \mathrm{mM})$ on the total cellular DNA content of cultured granulosa cells derived from the F1 (a), F2 (b) and F3/4 (c) follicles. Values are means \pm S.E.M. $(n=6$ independent cultures); within each panel, means without a common letter are significantly different $(P<0.05)$.

cells. LH alone raised LHR transcript level 2.5-fold $(P<0.01)$ in $\mathrm{F} 1$ cells and 1.6 -fold $(P<0.01)$ in F2 cells with no effect on F3/4 cells. Treatment with 8-Br-cAMP alone increased LHR transcript level $\sim$ two-, three- and fourfold in F1, F2 and F3/4 cells respectively $(P<0.001)$. For each follicle position co-treatment with BMP-6 and FSH up-regulated LHR transcript levels two- to fourfold relative to those induced by either treatment alone. Similarly, co-treatment with BMP-6 and LH further enhanced LHR transcript levels in all three cell populations $(P<0.001)$. Co-treatment with BMP-6 and 8-Br-cAMP resulted in a further twofold increase in LHR expression in $\mathrm{F} 1$ cells $(P<0.01)$ but there was no corresponding increase in F2 or F3/4 cells.

Figure $5 \mathrm{~d}-\mathrm{f}$ shows that treatment with BMP-6 alone raised FSHR transcript abundance by approximately twofold in $\mathrm{F} 1$ and $\mathrm{F} 2$ cells $(P<0.01)$ and approximately fivefold in $\mathrm{F} 3 / 4$ cells $(P<0.001)$. Neither $\mathrm{FSH}$ nor $\mathrm{LH}$ alone raised FSHR mRNA transcript abundance in any granulosa cell population; however, 8-Br-cAMP increased FSHR transcript approximately fourfold in F3/4 cells $(P<0.001)$. Co-treatment of cells with BMP-6 and either $\mathrm{FSH}, \mathrm{LH}$ or 8-Br-cAMP did not raise FSHR transcript abundance above the corresponding value induced by BMP-6 alone.

\section{Effects of BMP-6 alone and in combination with $L H$, FSH or 8-Br-cAMP on expression of $m R N A$ encoding cytochrome P450 scc}

Basal expression of cytochrome $\mathrm{P}^{450} 0_{\text {scc }}$ transcript was uniformly low amongst cells from F1, F2 and F3/4 follicles. Treatment with BMP-6 alone increased $\mathrm{P}^{4} 50_{\text {scc }}$ mRNA in F1 (25-fold), F2 (5.5-fold) and F3/4 (3.6-fold) cells. FSH alone increased transcript abundance in F1 (9.4-fold), F2 (4.4-fold) and F3/4 (3.3-fold) cells. $\mathrm{LH}$ alone also increased $\mathrm{P} 450_{\mathrm{scc}}$ expression in a follicle dependent manner (31-fold in F1;
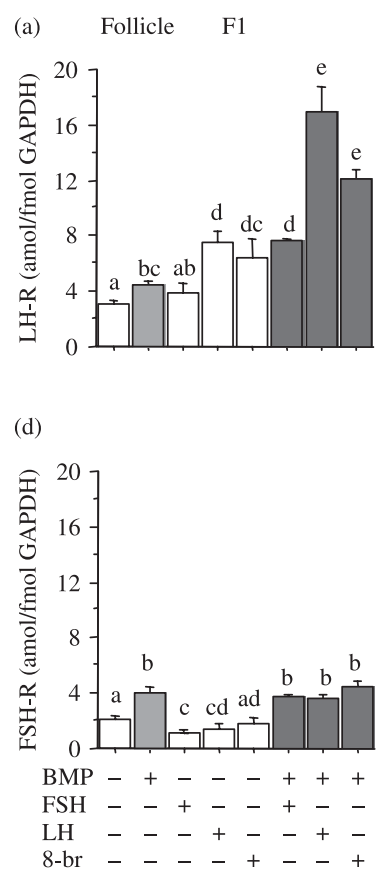
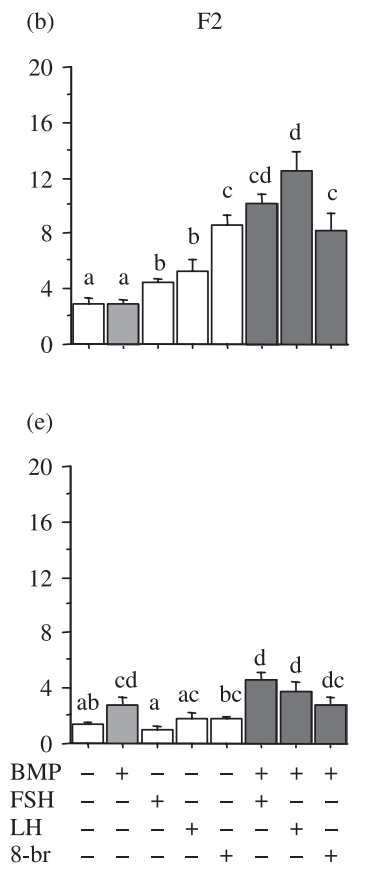
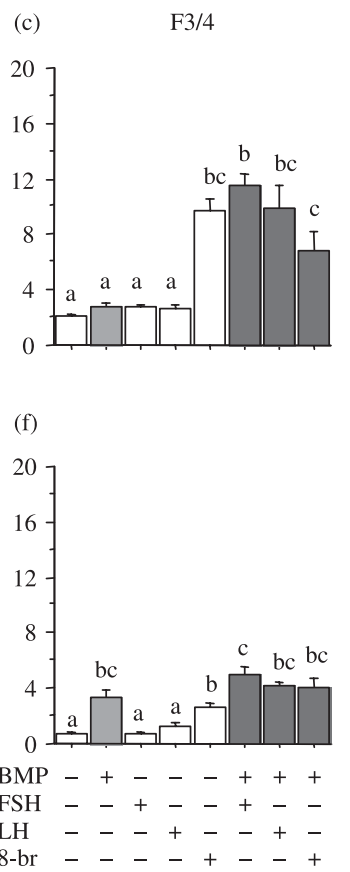

Figure 5 Effect of BMP-6 $(50 \mathrm{ng} / \mathrm{ml})$ with or without $\mathrm{FSH} / \mathrm{LH}(100 \mathrm{ng} / \mathrm{ml})$ or 8 -Br-cAMP $(0.5 \mathrm{mM})$ on relative amounts of mRNA transcript encoding the $\mathrm{LH}(\mathrm{a}-\mathrm{C})$ and $\mathrm{FSH}$ $(d-f)$ receptors in the F1, F2 and F3/4 preovulatory granulosa cells. Values are means \pm s.E.M. ( $n=3$ independent cultures); within each panel; means without a common letter are significantly different $(P<0.05)$. 


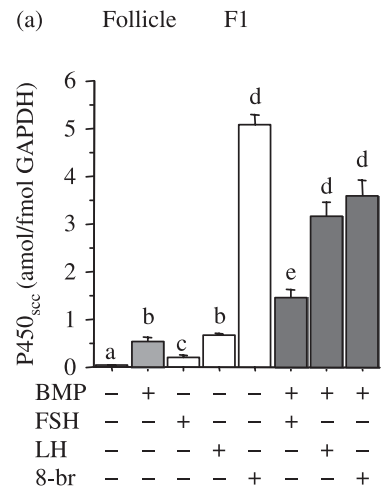

24-fold in F2; 19-fold in F3/4). Treatment with 8Br-cAMP alone greatly enhanced $\mathrm{P}^{4} 50_{\mathrm{scc}} \mathrm{mRNA}$ expression in the F1 (241-fold), F2 (53-fold) and F3/4 (48-fold) cells (Fig. 6).

In cells co-treated with BMP-6 and $\mathrm{FSH}, \mathrm{P} 450_{\text {scc }}$ mRNA showed a further increase over that induced by BMP-6 alone (F1 2.8-fold; F2 7.4-fold; F3/4 11.8-fold). Values were similarly raised in cells co-treated with BMP-6 and LH (F1 6.1-fold; F2 9.8-fold; F3/4 14.1-fold). In both cases, the enhancement was greatest in $\mathrm{F} 3 / 4$ follicles. Co-treatment with BMP-6 and 8-Br-cAMP did (c) F3/4

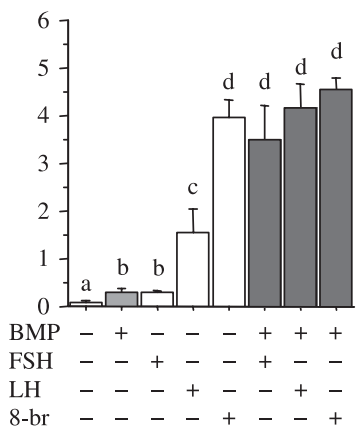

Figure 6 Effect of BMP-6 $(50 \mathrm{ng} / \mathrm{ml})$ with or without $\mathrm{FSH} / \mathrm{LH}(100 \mathrm{ng} / \mathrm{ml})$ or 8 -Br-cAMP $(0.5 \mathrm{mM})$ on relative amounts of $\mathrm{mRNA}$ transcript encoding cytochrome $\mathrm{P}_{450} \mathrm{scc}_{\mathrm{scc}}$ in F1 (a), F2 (b) and F3/4 (c) granulosa cells. Values are means \pm s.E.M. $(n=3$ independent cultures; within each panel, means without a common letter are significantly different $(P<0.05)$.

not raise $\mathrm{P} 450_{\text {scc }}$ transcript abundance over that in cells given 8-Br-cAMP alone (Fig. 6).

\section{Effects of BMP-6 alone and in combination with $L H$, FSH or 8-Br-cAMP on steady-state levels of mRNAs encoding the inhibin/activin subunits}

Effects of treatments on granulosa cell expression of mRNAs encoding the inhibin/activin $\alpha_{-}, \beta_{\mathrm{A}^{-}}$and $\beta_{\mathrm{B}^{-}}$ subunits are presented in Fig. 7. BMP-6 alone greatly increased amounts of the inhibin $\alpha$-subunit transcript in
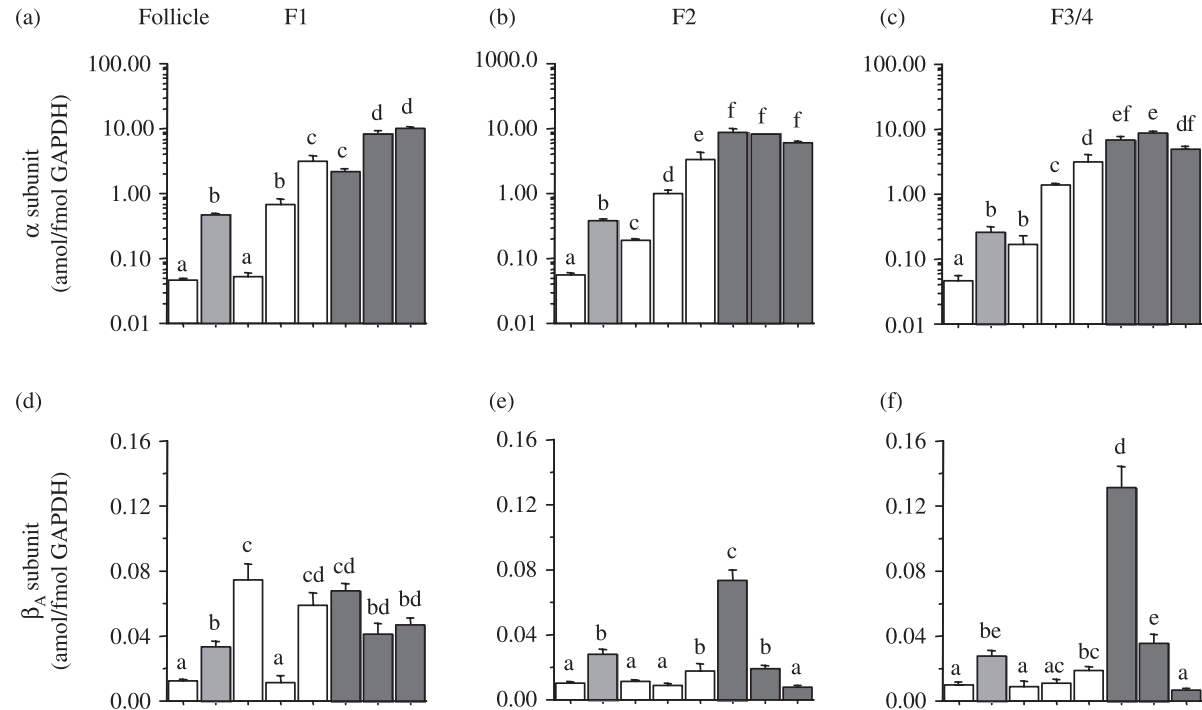

(g)

(h)
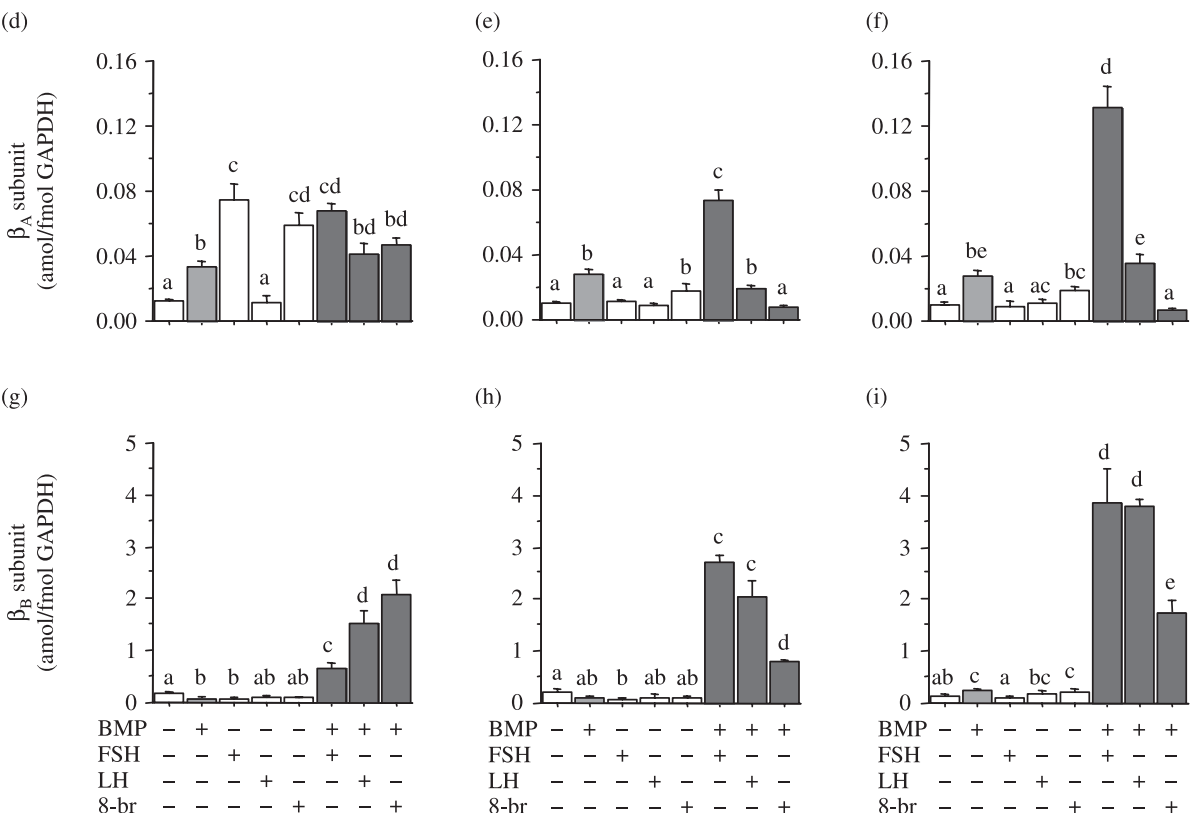

(i)

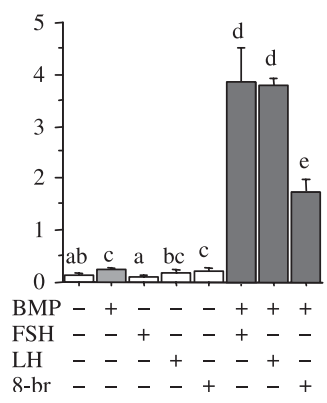

Figure 7 Effect of BMP-6 $(50 \mathrm{ng} / \mathrm{ml})$ with or without $\mathrm{FSH} / \mathrm{LH}(100 \mathrm{ng} / \mathrm{ml})$ or 8 $\operatorname{Br}$-cAMP $(0.5 \mathrm{mM})$ on relative amounts of mRNA transcript encoding the inhibi$\mathrm{n} /$ activin $\alpha\left(\mathrm{a}-\mathrm{C}\right.$; log scale), $\beta_{\mathrm{A}}(\mathrm{d}-\mathrm{f})$ and $\beta_{\mathrm{B}}$ (g-i) subunits in the $\mathrm{F} 1, \mathrm{~F} 2$ and $\mathrm{F} 3 / 4$ granulosa cells. Values are means \pm s.E.M. ( $n=3$ independent cultures); within each panel, means without a common letter are significantly different $(P<0.05)$. 
the F1 (10.5-fold), F2 (8.5 fold) and F3/4 cells (5.5-fold). To a lesser extent, BMP- 6 treatment raised $\beta_{A^{-}}$-subunit mRNA in the F1 (3-fold), F2 (2.5-fold) and F3/4 (2.5-fold) follicles. In contrast, BMP- 6 reduced $\beta_{\mathrm{B}}$-subunit mRNA amount in F1 cells (approximately threefold; $P<0.05$ ) and F2 cells (approximately twofold; NS), while enhancing $\beta_{\mathrm{B}}$ expression in F3/4 cells (twofold; $P<0.05)$. Addition of $\mathrm{FSH}$ alone raised inhibin $\alpha$-subunit mRNA amount in the F2 (5-fold) and F3/4 (3.5-fold) cells but not in F1 cells. In contrast, FSH increased the amount of the $\beta_{\mathrm{A}}$-subunit transcript in $\mathrm{F} 1$ cells (sixfold) without affecting $\beta_{\mathrm{A}}$ in F2 or F3/4 cells. FSH alone reduced $\beta_{\mathrm{B}}$-subunit mRNA abundance in F1 and F2 cells $(P<0.05)$ but not in F3/4 cells. Treatment with $\mathrm{LH}$ alone greatly enhanced the amount of inhibin $\alpha$-subunit mRNA transcript in F1 (13.5-fold) F2 (22-fold) and $F 3 / 4$ cells (30-fold), but did not affect $\beta_{\mathrm{A}}$ or $\beta_{\mathrm{B}}$ expression. Treatment with 8 -Br-cAMP alone greatly increased the amount of inhibin $\alpha$-subunit transcript with a similar response $(\sim 75$-fold $)$ in all the three cell populations. Like FSH, 8-Br-cAMP only stimulated $\beta_{\mathrm{A}}$ expression in $\mathrm{F} 1$ cells (fivefold) and had little or no effect on $\beta_{\mathrm{B}}$ transcript in any cell population.

BMP-6 co-treatment up-regulated $(P<0.001) \mathrm{FSH}$ induced inhibin $\alpha$ - (up to 65 -fold), $\beta_{A^{-}}$(up to 10 -fold) and $\beta_{\mathrm{B}^{-}}$(up to 40 -fold) subunit mRNA expression in all cell populations but with F1 cells showing a diminished response relative to $\mathrm{F} 3 / 4$ cells; $\mathrm{BMP}-6$ co-treatment did not raise the amount of $\beta_{\mathrm{A}}$ transcript in F1 cells above that induced by FSH alone.

BMP-6 also enhanced $(P<0.001) \mathrm{LH}$-induced inhibin $\alpha$ mRNA expression in F1 (12-fold), F2 (8-fold) and F3/4 cells (7-fold). In contrast to its effect on FSH-induced $\beta_{\mathrm{A}}$ mRNA, BMP-6 did not influence $\mathrm{LH}$-induced $\beta_{\mathrm{A}}$ mRNA level. However, BMP-6 greatly amplified LH-induced $\beta_{\mathrm{B}}$-subunit expression in the F1 (17-fold), F2 (18-fold) and $\mathrm{F} 3 / 4$ cells (20-fold) cells. As with FSH and $\mathrm{LH}$, there was a marked synergistic effect of 8-Br-cAMP and BMP-6 co-treatment on $\beta_{\mathrm{B}}$-subunit transcript abundance, the response being greatest in F1 cells (23-fold enhancement).

\section{Discussion}

The present study provides novel information on the effects of BMP-6 on basal and gonadotrophin-induced hormone secretion (inhibin- $A$, inhibin- $B$ and progesterone), steady-state mRNA expression (LH/FSH receptors, $\mathrm{P} 450_{\mathrm{scc}}$ inhibin/activin subunits) and cell proliferation/survival by chicken granulosa cells. As such, these findings constitute direct evidence to support the existence of a functional BMP system in the avian ovary that has a major influence on granulosa cell function.

Our initial RT-PCR survey of BMP ligand/receptor mRNA expression in cultured granulosa and theca cells from prehierarchical and preovulatory follicles indicated that cells of preovulatory F1 follicles show abundant mRNA expression for all three BMPR forms (BMPR-IA, $-\mathrm{IB},-\mathrm{II})$, consistent with the finding of Onagbesan et al. (2003), who examined mRNA expression in freshly dissected granulosa and theca layers from F1-F3 preovulatory chicken follicles. Theca cells from prehierarchical 6-8 $\mathrm{mm}$ follicles also expressed the three BMPRs but, in contrast, we found only weak expression of two of these receptors (BMPR-IA and-II) in granulosa cells from prehierarchical follicles. This supports the notion that hen granulosa cells acquire increased responsiveness to BMP ligands as follicles progress to the preovulatory stage.

With regard to potential, locally produced BMP ligand(s) that might serve to regulate granulosa cell function in the avian follicle, we found that hen granulosa cells express several BMP ligands; BMP-2 transcript was detected in prehierarchical cells, while BMP-2 and -4 (plus very weak BMP-3 and -5) transcripts were detected in preovulatory cells. Similarly, expression of BMP-2,-4,-6 and -7 has been reported in freshly isolated chicken granulosa cells from F1-F3 preovulatory follicles (Onagbesan et al. 2003). Thus, an autocrine/paracrine action of granulosa cell-derived BMPs in preovulatory follicle function is a distinct possibility. In comparison with granulosa cells, however, chicken theca cells showed abundant expression of a more extensive range of BMP ligands at both prehierarchical (BMP-3,-4,-5,-6,-7 and -15) and preovulatory (BMP-2,-3,-4,-5,-6 and -7) stages. At both stages theca cells also expressed the three BMPR forms, compatible with an autocrine/paracrine role of BMPs in modulating theca cell function from the prehierarchical stage through to ovulation. This finding is in agreement with Onagbesan et al. (2003), who reported that chicken theca layers from $\mathrm{F} 1$ to $\mathrm{F} 3$ preovulatory follicles express several BMP ligands (BMP-2,-4,-6 and -7) as well as BMPR-IA, -IB and -II. To our knowledge, this potential action on theca cell has yet to be explored in the chicken but recent studies in cattle (Glister et al. 2005) and sheep (Campbell et al. 2006) have demonstrated BMP-induced suppression of both basal and $\mathrm{LH}$-induced androgen secretion by theca cells.

Taken together with accumulating evidence supporting the existence of a functional BMP system in the mammalian ovary (for reviews, see Shimasaki et al. 2003, Juengel \& McNatty 2005, Knight \& Glister 2006) the above evidence of BMP ligand/receptor expression in avian follicles led to the principle hypothesis tested in this study that theca-derived BMPs exert a paracrine action on neighbouring granulosa cells to modulate hormone secretion and cell proliferation in a follicle stage-related manner. To test this hypothesis, we carried out functional in vitro studies on granulosa cells isolated from preovulatory (F1, F2 and F3/4) follicles. We decided to focus on BMP- 6 here, as we found its mRNA to be expressed by chicken theca but not granulosa cells. 
Moreover, BMP-6 (albeit human recombinant material) was readily available in a pure bioactive form and, to our knowledge, there have been no previous studies investigating the potential action(s) of this BMP in the avian ovary.

We first examined the effects of BMP- 6 on basal and gonadotrophin-induced secretion of two granulosa cellderived hormones that are produced in increasing amounts by chicken follicles as they progress through the preovulatory hierarchy, namely inhibin-A and progesterone (Etches \& Duke 1984, Robinson \& Etches 1986, Lovell et al. 1998). In the absence of gonadotrophin stimulation, BMP-6 promoted a marked dosedependent increase in granulosa cell secretion of both inhibin-A (up to 75-fold) and progesterone (4-fold) with the inhibin-A response being greatest in F3/4 follicles and the progesterone response being greatest in $\mathrm{F} 1$ follicles. The magnitude of the BMP-6-induced rise in inhibin-A secretion was substantially greater than that elicited by either FSH or LH alone suggesting an important physiological role for this potential thecaderived protein. BMP- 6 was also found to synergise with $\mathrm{LH}$ and $\mathrm{FSH}$, raising inhibin-A and progesterone secretion by up to 100 -fold over basal values. Previous studies have shown that other TGF $\beta$ superfamily members, namely activin-A (Lovell et al. 2002b) and BMP-4 and -7 (Onagbesan et al. 2003), can enhance basal and gonadotrophin-dependent progesterone secretion and cell proliferation/survival by chicken granulosa cell from preovulatory follicles, but this is the first study to examine BMP-dependent inhibin secretion in birds.

In contrast, the stimulatory effect of BMP-6 on chicken granulosa cell hormone secretion and expression of mRNA for $\mathrm{P}^{4} 50_{\mathrm{scc}}$ and inhibin subunits reported here, studies on rat granulosa cells have shown that BMP-6 inhibits $\mathrm{FSH}$-induced progesterone secretion, an action associated with a decrease in StAR and $\mathrm{P}^{4} 50_{\mathrm{scc}} \mathrm{mRNA}$ expression (Otsuka et al. 2001). Inhibitory effects of BMP-6 on basal and/or FSH-dependent progesterone secretion by granulosa cells have been reported for other mammals including cattle (Glister et al. 2004), sheep (Pierre et al. 2005) and pigs (Brankin et al. 2005).

As the receptor-mediated actions of both FSH and LH are transduced, at least in part, by a cAMP/PKAdependent signalling pathway (Ascoli et al. 2002, Conti 2002), we also compared the effects of BMP-6 on granulosa cell responses induced by the membranepermeable cAMP analogue, 8-Br-cAMP. This experiment showed that, in contrast to its synergistic action on gonadotrophin-induced hormone secretion, BMP-6 did not further enhance 8-Br-cAMP-induced inhibin-A or progesterone secretion. This observation lends support to the view that BMP-6 potentiates LH/FSH action by interacting with their signalling pathways at a level upstream of cAMP generation, perhaps involving up-regulation of $\mathrm{LH}$ and/or $\mathrm{FSH}$ receptor mRNA expression.

To test this, we used real-time Q-PCR (TaqMan) assays to quantify steady-state levels of mRNAs encoding FSH and $\mathrm{LH}$ receptors in F1, F2 and F3/4 granulosa cells exposed to the same treatment combinations. Treatment of cells with BMP-6 alone did indeed up-regulate expression of $\mathrm{FSH}$ receptor mRNA up to fivefold (greatest increase in F3/4 cells) supporting this hypothesis. However, BMP-6 alone only promoted a small (twofold) increase in $\mathrm{LH}$ receptor transcript level, a response that was confined to F1 cells and thus unlikely to account for the synergistic action of BMP-6 and LH/FSH on progesterone secretion that was also observed in F2 and F3/4 granulosa cells. Examination of gonadotrophin receptor mRNA in cells co-treated with BMP-6 and gonadotrophin largely resolved this inconsistency. We found that $\mathrm{LH}$ receptor transcript level in all three cell populations was augmented (up to sixfold) by co-treatment with BMP-6 and either FSH or LH. In contrast, co-treatment with BMP-6 and gonadotrophin had little or no effect on FSH receptor expression above that seen in cells treated with BMP-6 alone. In rat granulosa cells, BMP-6 alone had no effect on FSH or LH receptor mRNA expression, but suppressed FSH-induced and forskolininduced expression of both transcripts (Otsuka et al. 2001). Again, this differs markedly from the present finding in the chicken that BMP- 6 enhances basal and gonadotrophin-dependent mRNA expression for both FSH and $\mathrm{LH}$ receptors.

Thus, through an intracellular mechanism(s) that has yet to be defined, BMP-6 (presumably acting via type I and type II BMPRs on the cell surface) can up-regulate expression of both $\mathrm{FSH}$ and $\mathrm{LH}$ receptors. Furthermore, it appears that BMP- 6 can up-regulate $\mathrm{FSH}$ receptor $\mathrm{mRNA}$ expression in the absence of gonadotrophin, while BMP6 dependent up-regulation of $\mathrm{LH}$ receptor mRNA requires co-stimulation with gonadotrophin (at least in F2 and F3/4 follicles). The possibility cannot be excluded that the observed increases in steady-state mRNA transcript levels reflect a BMP-6-induced increase in mRNA stability, rather than an up-regulation of gene transcription per se. Either way, it seems highly likely from the functional end points monitored here (i.e. gonadotrophin-induced inhibin-A and progesterone secretion) that the increased gonadotrophin receptor mRNA transcript levels are indeed associated with increased expression of functional LH and FSH receptor proteins on the granulosa cell surface. Further studies are needed to elucidate the intracellular signalling mechanisms by which the Smad pathway activated by BMP-6 interacts with the gonadotrophin-induced signalling pathway(s) to alter granulosa cell gonadotrophin receptor mRNA expression and/or stability.

Of course, the observed synergism between BMP-6 and gonadotrophin could be interpreted as a gonadotrophin-dependent up-regulation of BMP-signalling 
rather than vice versa. Indeed, a recent report (Miyoshi et al. 2006) that FSH can enhance BMP-induced Smad 1/ $5 / 8$ phosphorylation in a human ovarian granulosa-like tumour cell line supports this concept. It should be pointed out that different BMPs can also bind to and form signalling complexes with certain activin receptor subtypes (for reviews, see Knight \& Glister 2003, Miyazono et al. 2005) and in a recent study (Lovell et al. in press), we showed that both $\mathrm{LH}$ and $\mathrm{FSH}$ augmented ActR-I and ActR-IIB mRNA levels in chicken granulosa cells from F1 follicles; further studies are warranted to investigate whether gonadotrophins modulate granulosa cell expression of BMPR subtypes and their associated downstream signal transduction components.

To gain further insights into the mechanism by which BMP-6 enhanced inhibin-A protein secretion, mRNA transcripts encoding the inhibin/activin subunits $\left(\alpha, \beta_{\mathrm{A}}\right.$ and $\beta_{B}$ ) were also quantified. Consistent with the BMP-6induced increase in granulosa cell secretion of inhibin- $A$ $\left(\alpha-\beta_{\mathrm{A}}\right.$ dimer), treatment with BMP-6 alone was associated with a marked increase in inhibin $\alpha$ - and $\beta_{A}$-subunit mRNA abundance but did not affect $\beta_{B}$-subunit mRNA. Moreover, co-treatment with BMP-6 and either FSH, LH or cAMP analogue further enhanced $\alpha$ subunit mRNA expression to a similar extent in cells from F1, F2 and F3/4 follicles. However, there was an interesting difference between the $\beta_{\mathrm{A}}$ responses to the different BMP-6 co-treatments: a further rise in $\beta_{\mathrm{A}}$ mRNA level was observed with FSH co-treatment but not with $\mathrm{LH}$ or cAMP analogue co-treatment, despite the fact that all three co-treatments raised inhibin-A protein secretion. This casts some doubt on the generally held view that the level of $\beta_{A^{-}}$-subunit mRNA is rate-limiting for inhibin-A synthesis (Ying 1988, Meunier et al. 1988, Chen \& Johnson 1996, 1997, Fu et al. 2001) and suggests that other posttranslational events may be limiting, at least in some circumstances.

Perhaps the most striking and unexpected finding to emerge from the Q-PCR analysis of inhibin/activin subunit expression was the dramatic increase in the amount of $\beta_{\mathrm{B}}$ mRNA transcript observed in granulosa cells co-treated with BMP- 6 and either FSH, LH or CAMP analogue. No such increase was observed in cells given either BMP-6 alone or gonadotrophin/cAMP analogue alone indicating a marked synergism between BMP-6 and gonadotrophin-dependent/cAMP-dependent signalling pathways with respect to $\beta_{\mathrm{B}}$ expression. It is also notable that the magnitude of the $\beta_{\mathrm{B}}$ response to FSH or $\mathrm{LH}$ co-treatment was greatest in $\mathrm{F} 3 / 4$ cells and lowest in F1 cells. Using the present inhibin-B assay, we observed a modest increase in inhibin-B protein secretion by cells treated with BMP-6 alone or BMP-6 with either FSH or $\mathrm{LH}$. Due to the relatively poor assay sensitivity, we cannot assign fold increases to these responses as basal levels were below our detection limit. Nonetheless, secretion was greatest in the F3/4 granulosa cells co-treated with BMP-6 and LH.

Interestingly, treatment of human granulosa lutein cells with activin-A (Eramaa et al. 1995) and BMP-2 or -6 (Jaatinen et al. 2002) was reported to selectively enhance $\beta_{\mathrm{B}}$-subunit expression and inhibin-B protein secretion without affecting $\alpha$ or $\beta_{\mathrm{A}}$-subunit expression. Furthermore treatment with human chorionic gonadotrophin alone had no effect on $\beta_{\mathrm{B}}$ expression but suppressed the activin or BMP-induced induction of $\beta_{B}$-subunit expression and inhibin-B secretion. We cannot rule out the possibility that increased expression of $\beta_{B}$-subunit mRNA leads to an increased synthesis of activin $B\left(\beta_{B}-\beta_{B}\right.$ dimer) or activin $A B\left(\beta_{A}-\beta_{B}\right.$ dimer). While we do not have immunoassays for chicken activin $B$ or $A B, a$ recent immunoblotting study on chicken granulosa cell-conditioned culture medium was unable to detect secretion of any activin isoform (Johnson et al. 2005). Previous attempts to measure activin-A secretion by cultured hen granulosa cells in this laboratory have also been unsuccessful (Lovell et al. 2002b) despite the presence of low, but detectable amounts of activin-A in granulosa cell extracts from hierarchical follicles (Lovell et al. 1998, 2003).

In conclusion these findings constitute direct evidence that intra-ovarian BMPs of thecal origin have a key paracrine role in modulating granulosa cell function in a preovulatory follicle stage-dependent manner in the avian ovary. We speculate that developmental changes in intra-follicular BMP signalling might account for differential expression of gonadotrophin receptors, steroidogenic enzymes and inhibin subunits leading to the dramatic shift in the pattern of steroid output and inhibin-A/inhibin-B production (Lovell et al. 2003, Johnson et al. 2005) that accompanies follicle development.

\section{Acknowledgements}

We are grateful to Mr S A Feist for technical assistance, Dr A F Parlow (NHPP, Torrance, CA, USA) for supplying purified ovine FSH and LH, Prof. NP Groome (Oxford Brookes University, Oxford, UK) for inhibin monoclonal antibodies and NIBSC for recombinant human inhibin-A. This work was supported by the BBSRC. The authors declare that there is no conflict of interest that would prejudice the impartiality of this scientific work.

\section{References}

Armstrong DG 1984 Ovarian aromatase activity in the domestic fowl (Gallus domesticus). Journal of Endocrinology 100 81-86.

Ascoli M, Fanelli F \& Segaloff DL 2002 The lutropin/choriogonadotropin receptor, a 2002 perspective. Endocrine Reviews 23 14-174.

Bahr JM, Wang S-C, Huang MY \& Calvo FO 1983 Steroid concentrations in isolated theca and granulosa layers of preovulatory follicles during the ovulatory cycle of the domestic hen. Biology of Reproduction 29 326-334. 
Bodensteiner KJ, Clay CM, Moeller CL \& Sawyer HR 1999 Molecular cloning of the ovine growth/differentiation factor-9 gene and expression of growth/differentiation factor-9 in ovine and bovine ovaries. Biology of Reproduction 60 381-386.

Brankin V, Quinn RL, Webb R \& Hunter MG 2005 Evidence for a functional bone morphogenetic protein (BMP) system in the porcine ovary. Domestic Animal Endocrinology 28 367-379.

de Caestecker M 2004 The transforming growth factor- $\beta$ superfamily of receptors. Cytokine and Growth Factor Reviews 15 1-11.

Calvo FO \& Bahr JM 1982 Hormone stimulable adenylyl cyclase system in the granulosa cells of the domestic hen (Gallus domesticus). General and Comparative Endocrinology 48 452-461.

Calvo FO \& Bahr JM 1983 Adenylyl cyclase system of the small preovulatory follicles of the domestic hen: responsiveness to folliclestimulating hormone and luteinizing hormone. Biology of Reproduction 29 542-547.

Campbell BK, Souza CJ, Skinner AJ, Webb R \& Baird DT 2006 Enhanced response of granulosa and theca cells from sheep carriers of the FecB mutation in vitro to gonadotropins and bone morphogenic protein-2, -4, and -6. Endocrinology 147 1608-1620.

Chen CC \& Johnson PA 1996 Expression of inhibin $\alpha$ and inhibin/activin $\beta$ A subunits in the granulosa layer of the large preovulatory follicles of the hen. Biology of Reproduction $\mathbf{5 5}$ 450-454

Chen CC \& Johnson PA 1997 Expression and regulation of mRNA for inhibin/activin $\alpha$ - and $\beta A$-subunits in the granulosa layer of the two largest preovulatory follicles during the hen ovulatory cycle. General and Comparative Endocrinology 107 386-393.

Chomczynski P \& Sacchi N 1987 Single-step method of RNA isolation by acid guanidinium thiocyanate-phenol-chloroform extraction. Analytical Biochemistry 162 156-159.

Conti M 2002 Specificity of the cyclic adenosine 3', $5^{\prime}$-monophosphate signal in granulosa cell function. Biology of Reproduction 67 1653-1661.

Derynck R \& Zhang YE 2003 Smad-dependent and Smad-independent pathways in TGF- $\beta$ family signalling. Nature 425 577-584.

Eramaa M, Hilden K, Tuuri T \& Ritvos O 1995 Regulation of inhibin/activin subunit messenger ribonucleic acids (mRNAs) by activin A and expression of activin receptor mRNAs in cultured human granulosa-luteal cells. Endocrinology 136 4382-4389.

Erickson GF \& Shimasaki S 2003 The spatiotemporal expression pattern of the bone morphogenetic protein family in rat ovary cell types during the estrous cycle. Reproductive Biology and Endocrinology 19.

Etches RJ \& Duke CE 1984 Progesterone, androstenedione and oestradiol content of theca and granulosa tissue of the four largest ovarian follicles during the ovulatory cycle of the hen (Gallus domesticus). Journal of Endocrinology 103 71-76.

Etches RJ \& Schoch JP 1984 A mathematical representation of the ovulatory cycle of the domestic hen. British Poultry Science 25 $65-76$.

Fu Y, Niu D, Ruan H, Yu XP, Chen G, He GQ \& Yang PX 2001 Expression of inhibin $\alpha$ and inhibin/activin $\beta$ A subunits in the developing follicles of the duck. Acta Genetica Sinica 28 502-509.

Gilbert AB, Evans AJ, Perry MM \& Davidson MH 1977 A method for separating the granulosa cells, the basal lamina and the theca of the preovulatory ovarian follicle of the domestic fowl (Gallus domesticus). Journal of Reproduction and Fertility 50 179-181.

Gilbert AB, Perry MM, Waddington D \& Hardie MA 1983 Role of atresia in establishing the follicular hierarchy in the ovary of the domestic hen (Gallus domesticus). Journal of Reproduction and Fertility $69221-227$.

Glister C, Kemp CF \& Knight PG 2004 Bone morphogenetic protein (BMP) ligands and receptors in bovine ovarian follicle cells: actions of BMP-4, -6 and -7 on granulosa cells and differential modulation of Smad-1 phosphorylation by follistatin. Reproduction 127 239-254.

Glister C, Richards SL \& Knight PG 2005 Bone morphogenetic proteins (BMP) $-4,-6$, and -7 potently suppress basal and luteinizing hormone-induced androgen production by bovine theca interna cells in primary culture: could ovarian hyperandrogenic dysfunction be caused by a defect in thecal BMP signaling? Endocrinology 146 1883-1892.

Groome NP, Illingworth PJ, O'Brien M, Par R, Rodger FE, Mather JP \& McNeilly AS 1996 Measurement of dimeric inhibin B throughout the human menstrual cycle. Journal of Clinical Endocrinology and Metabolism 81 1401-1405.

Huang ES-R \& Nalbandov AV 1979 Steroidogenesis of chicken granulosa and theca cells: in vitro incubation system. Biology of Reproduction 20 442-453.

Huang ES-R, Kao KJ \& Nalbandov AV 1979 Synthesis of sex steroids by cellular components of chicken follicles. Biology of Reproduction $\mathbf{2 0}$ 454-461.

Huse M, Chen YG, Massague J \& Kuriyan J 1999 Crystal structure of the cytoplasmic domain of the type I TGF $\beta$ receptor in complex with FKBP12. Cell 96 425-436.

Jaatinen R, Bondestam J, Raivio T, Hilden K, Dunkel L, Groome N \& Ritvos O 2002 Activation of the bone morphogenetic protein signaling pathway induces inhibin $\beta(B)$-subunit mRNA and secreted inhibin B levels in cultured human granulosa-luteal cells. Journal of Clinical Endocrinology and Metabolism 87 1254-1261.

Johnson PA, Brooks CF \& Davis AJ 2005 Pattern of secretion of immunoreactive inhibin/activin subunits by avian granulosa cells. General and Comparative Endocrinology 141 233-239.

Juengel JL \& McNatty KP 2005 The role of proteins of the transforming growth factor- $\beta$ superfamily in the intraovarian regulation of follicular development. Human Reproduction Update 11 143-160.

Kato M, Shimada K, Saito N, Noda K \& Ohta M 1995 Expression of P45017 $\alpha$-hydroxylase and P450aromatase genes in isolated granulosa, theca interna, and theca externa layers of chicken ovarian follicles during follicular growth. Biology of Reproduction $\mathbf{5 2}$ 405-410.

Knight PG \& Glister C 2003 Local roles of TGF- $\beta$ superfamily members in the control of ovarian follicle development. Animal Reproduction Science 78 165-183.

Knight PG \& Glister C 2006 TGF- $\beta$ superfamily members and ovarian follicle development. Reproduction 132 191-206.

Knight PG \& Muttukrishna S 1994 Measurement of dimeric inhibin using a modified two-site immunoradiometric assay specific for oxidized (Met O) inhibin. Journal of Endocrinology 141 417-425.

Labarca C \& Paigen K 1980 A simple, rapid, and sensitive DNA assay procedure. Analytical Biochemistry 102 344-352.

Lee HT \& Bahr JM 1989 Inhibitory sites of androgens and estradiol in progesterone biosynthesis in granulosa cells of the domestic hen. Endocrinology 125 760-765.

Lovell TM, Gladwell RT, Cunningham FJ, Groome NP \& Knight PG 1998 Differential changes in inhibin A, activin A, and total $\alpha$-subunit levels in granulosa and theca layers of developing preovulatory follicles in the chicken. Endocrinology 139 1164-1171.

Lovell TM, Vanmontfort D, Bruggeman V, Decuypere E, Groome NP, Knight PG \& Gladwell RT 2000 Circulating concentrations of inhibin-related proteins during the ovulatory cycle of the domestic fowl (Gallus domesticus) and after induced cessation of egg laying. Journal of Reproduction and Fertility 119 323-328.

Lovell TM, Gladwell RT, Groom NP \& Knight PG 2002a Modulatory effects of gonadotrophins and insulin-like growth factor on the secretion of inhibin $\mathrm{A}$ and progesterone by granulosa cells from chicken preovulatory (F1-F3) follicles. Reproduction 123 291-300.

Lovell TM, Gladwell RT, Groome NP \& Knight PG 2002 $b$ Differential effects of activin $A$ on basal and gonadotrophin-induced secretion of inhibin A and progesterone by granulosa cells from preovulatory (F1-F3) chicken follicles. Reproduction 124 649-657.

Lovell TM, Gladwell RT, Groome NP \& Knight PG 2003 Ovarian follicle development in the laying hen is accompanied by divergent changes in inhibin $\mathrm{A}$, inhibin $\mathrm{B}$, activin $\mathrm{A}$ and follistatin production in granulosa and theca layers. Journal of Endocrinology 177 45-55.

Lovell TM, Al-Musawi SL, Gladwell RT \& Knight PG 2007 Gonadotrophins modulate hormone secretion and steady-state mRNA 
levels for activin receptors (type I, IIA, IIB) and inhibin co-receptor (betaglycan) in granulosa and theca cells from chicken prehierarchical and preovulatory follicles. Reproduction 133 1159-1168.

Marrone BL \& Hertelendy F 1983 Steroidogenesis by avian ovarian cells: effects of luteinizing hormone and substrate availability. American Journal of Physiology 244 487-493.

Marsh JM 1975 The role of cyclic AMP in gonadal function. Advances in Cyclic Nucleotide Research 6 137-199.

McNatty KP, Juengel JL, Wilson T, Galloway SM, Davis GH, Hudson NL, Moeller CL, Cranfield M, Reader KL, Laitinen MP, Groome NP, Sawyer HR \& Ritvos O 2003 Oocyte-derived growth factors and ovulation rate in sheep. Reproduction 61 339-351.

Meunier H, Cajander SB, Roberts VJ, Rivier C, Sawchenko PE, Hsueh AJ \& Vale W 1988 Rapid changes in the expression of inhibin $\alpha-, \beta A-$, and $\beta$ B-subunits in ovarian cell types during the rat estrous cycle. Molecular Endocinology 2 1352-1363.

Miyazono K, Maeda S \& Imamura T 2005 BMP receptor signaling: transcriptional targets, regulation of signals, and signaling cross-talk. Cytokine and Growth Factor Reviews 16 251-263.

Miyoshi T, Otsuka F, Suzuki J, Takeda M, Inagaki K, Kano Y, Otani H, Mimura Y, Ogura T \& Makino H 2006 Mutual regulation of folliclestimulating hormone signaling and bone morphogenetic protein system in human granulosa cells. Biology of Reproduction $\mathbf{7 4}$ 1073-1082.

Muttukrishna S, Fowler PA, Groome NP, Mitchell GG, Robertson WR \& Knight PG 1994 Serum concentrations of dimeric inhibin during the spontaneous human menstrual cycle and after treatment with exogenous gonadotrophin. Human Reproduction 9 1634-1642.

Onagbesan OM, Bruggeman V, Van As P, Tona K, Williams J \& Decuypere E 2003 BMPs and BMPRs in chicken ovary and effects of BMP-4 and -7 on granulosa cell proliferation and progesterone production in vitro. American Journal of Physiology, Endocrinology and Metabolism 285 973-983.

Otsuka F, Moore RK \& Shimasaki S 2001 Biological function and cellular mechanism of bone morphogenetic protein- 6 in the ovary. Journal of Biological Chemistry 276 32889-32895.
Pierre A, Pisselet C, Monget P, Monniaux D \& Fabre S 2005 Testing the antagonistic effect of follistatin on BMP family members in ovine granulosa cells. Reproduction, Nutrition, Development 45 419-425.

Quinn RL, Shuttleworth G \& Hunter MG 2004 Immunohistochemical localization of the bone morphogenetic protein receptors in the porcine ovary. Journal of Anatomy 205 15-23.

Robinson FE \& Etches RJ 1986 Ovarian steroidogenesis during follicular maturation in the domestic fowl (Gallus domesticus). Biology of Reproduction 35 1096-1105.

Sauer MJ, Foulkes JA, Worsfold A \& Morris BA 1986 Use of progesterone 11-glucuronide-alkaline phosphatase conjugate in a sensitive microtitre-plate enzyme immunoassay of progesterone in milk and its application to pregnancy testing in dairy cattle. Journal of Reproduction and Fertility 76 375-391.

Shimasaki S, Zachow RJ, Li D, Kim H, lemura S, Ueno N, Sampath K, Chang RJ \& Erickson GF 1999 A functional bone morphogenetic protein system in the ovary. PNAS 96 7282-7287.

Shimasaki S, Moore RK, Erickson GF \& Otsuka F 2003 The role of bone morphogenetic proteins in ovarian function. Reproduction 61 323-337.

Streb H, Irvine RF, Berridge MJ \& Schulz I 1983 Release of $\mathrm{Ca}^{2+}$ from a nonmitochondrial intracellular store in pancreatic acinar cells by inositol-1,4,5-trisphosphate. Nature 306 67-69.

Warren DC \& Scott HM 1935 The time factor in egg formation. Poultry Science 14 195-207.

Wrana JL, Attisano L, Wieser R, Ventura F \& Massague J 1994 Mechanism of activation of the TGF- $\beta$ receptor. Nature 370 341-347.

Ying SY 1988 Inhibins, activins, and follistatins: gonadal proteins modulating the secretion of follicle-stimulating hormone. Endocrine Reviews 9 267-293.

Received 9 February 2007

First decision 6 March 2007

Revised manuscript received 23 April 2007

Accepted 3 May 2007 